\title{
Analisis Prosedur Administrasi Peralihan Hak Atas Tanah Hibah pada Kementerian Agraria dan Tata Ruang / Badan Pertanahan Nasional Kabupaten Bungo Provinsi Jambi
}

\author{
Mardansyah $^{1}$ \\ ${ }^{1}$ STIA Setih Setio Muara Bungo, Kabupaten Bungo, Jambi, Indonesia
}

\section{INFORMASI ARTIKEL}

Sejarah Artikel:

Diterima Redaksi: 15 Juli 2020

Revisi Akhir: 30 Juli 2020

Diterbitkan Online: 22 Agustus 2020

KATA KUNCI

Prosedur, Administrasi, Hak Atas Tanah Hibah

\section{KORESPONDENSI}

No HP: 085266989901

E-mail: mardansyah777@gmail.com

\begin{abstract}
A B $\mathbf{S}$ T $\mathbf{R}$ A $\mathbf{C}$ T
This research was conducted due to several problems including: the absence of efforts to transfer land rights according to clear procedures and conditions, the absence of legal certainty and protection for holders of land rights grants. This research was conducted on 20 people involved in the Ministry of Agrarian Affairs and Spatial Planning/National Land Agency Bungo Regency of Bungo Regency using a survey method with a descriptive qualitative approach. The results of the research show the procedures for administering the transfer of rights to land grants at the Ministry of Agrarian Affairs and Spatial Planning. Procedures for administering the transfer of land rights to the grant, for land that has been certified by the grantee and the grantee before the official land deed maker (PPAT) to sign the grant deed. In the process of making a grant deed, the grant giver must complete land data and data on the grantee and recipient of the grant. Obstacles to the Office of the Ministry of Agrarian Affairs in the Transfer of Rights to Land Grants is the high number of people who do not understand about the transfer of rights to land grants, underutilized office facilities and infrastructure, lack of employee discipline.
\end{abstract}

\section{PENDAHULUAN}

Tanah merupakan sumber kehidupan bagi makhluk hidup baik manusia, hewan, atau tumbuh-tumbuhan. Manusia hidup dan tinggal di atas tanah dan memanfaatkan tanah untuk sumber kehidupan dengan menanam tumbuh-tumbuhan yang menghasilkan makanan. Mengingat begitu pentingnya tanah karena dapat menghasilkan sumber daya alam yang sangat bermanfaat bagi orang banyak maka perlu diatur oleh pemerintah. Undang- Undang Dasar 1945 Pasal 33 ayat 3 berbunyi : "Bumi dan air dan kekayaan alam yang terkandung di dalamnya dikuasai oleh negara dan dipergunakan untuk sebesarbesar kemakmuran rakyat".

Oleh karena itu, sudah semestinya pemanfaatan fungsi bumi dan air, dan kekayaan yang terkandung di dalamnya adalah ditujukan untuk mencapai sebesar-besarnya kemakmuran seluruh rakyat Indonesia. Hak menguasai dari Negara memberi wewenang untuk :

1. Mengatur dan menyelenggarakan peruntukan, penggunaan, persediaan dan pemeliharaan bumi, air dan ruang angkasa.

2. Menentukan dan mengatur hubungan-hubungan hukum antara orang-orang dengan bumi, air dan ruang angkasa.

3. Menentukan dan mengatur hubungan-hubungan hukum antara orang-orang dengan perbuatanperbuatan hukum mengenai bumi, air dan ruang angkasa.

Berdasarkan hak menguasai oleh Negara sebagaimana di atas dan mengingat begitu pentingnya tanah bagi manusia, maka 
penguasaan atas tanah diatur UUPA ( Undang-undang No.5 tahun 1960 tentang pokok-pokok agraria ) yang kemudian ditentukan macam-macam hak atas permukaan bumi, yang disebut tanah, yang dapat diberikan kepada dan dipunyai oleh orang-orang baik sendiri maupun bersama-sama dengan orang-orang lain serta badan hukum.

Hak-hak Atas Tanah dimaksud memberi kewenangan untuk mempergunakan tanah, bumi dan air serta ruang angkasa yang ada diatasnya untuk kepentingan yang langsung berhubungan dengan penggunaan tanah itu sesuai dengan ketentuan hukum yang berlaku. Selain Hak-hak Atas Tanah juga ditentukan Hak-hak atas air dan ruang angkasa. Dalam Undang - Undang Nomor 5 Tahun 1960 tentang Peraturan Dasar Pokok- Pokok Agraria Pasal 16 ayat 1 menyebutkan :

1) Hak - hak atas tanah ialah

a. Hak Milik,

b. Hak Guna Usaha,

c. Hak Guna Bangunan,

d. Hak Pakai,

e. Hak Sewa,

f. Hak Membuka Tanah,

g. Hak Memungut Hasil Hutan,

h. Hak - hak lain yang tidak termasuk dalam hak-hak tersebut di atas yang akan ditetapkan dengan undang undang serta hak - hak yang sifatnya sementara.

Saat ini tanah bagi masyarakat merupakan harta kekayaan yang memiliki nilai jual yang tinggi karena fungsinya sebagai sumber kehidupan masyarakat, sehingga setiap jengkal tanah dipertahankan hinnga akhir hayat. Saat ini pembangunan di segala bidang terus dilakukan oleh Bangsa Indonesia. Dengan demikian fungsi tanahpun mengalami perkembangan sehingga kebutuhan masyarakat akan hak atas tanah juga terus mengalami perkembangan.

Jumlah tanah yang tetap dan kebutuhan akan tanah yang semakin meningkat karena pertumbuhan penduduk di Indonesia yang sangat tinggi membuat tidak seimbangnya antara persediaan tanah dengan kebutuhan tanah itu dapat memicu timbulnya berbagai macam permasalahan. Kegiatan pembangunan yang memerlukan tanah sebagai media dengan dilaksanakan oleh pemerintah melalui pembebasan tanah serta pertumbuhan penduduk yang sangat tinggi di Indonesia membuat tingginya kegiatan peralihan hak atas tanah. Pemegang hak atas tanah saat ini bukanlah pemegang hak atas tanah yang pertama. Akibatnya baik pemerintah maupun masyarakat ketika membutuhkan sebidang tanah untuk memenuhi kebutuhannya memerlukan kepastian mengenai siapa sebenarnya pemilik bidang tanah tersebut.

Untuk memperoleh suatu hak atas tanah, tiap-tiap orang atau individu dapat memperoleh hak atas tanah dengan prosedur dan aturan yang ada untuk memperoleh hak atas tanah.

Peralihan hak atas tanah merupakan suatu perbuatan hukum yang bertujuan memindahkan hak dari satu pihak ke pihak lain. Salah satu dari peralihan hak atas tanah adalah melalui Hibah. Hibah yaitu suatu persetujuan dalam mana suatu pihak berdasarkan atas kemurahan hati, perjanjian dalam hidupnya memberikan hak milik atas suatu barang kepada pihak kedua secara percuma dan yang tidak dapat ditarik kembali, sedangkan pihak kedua menerima baik penghibahan ini.

Peralihan hak atas tanah merupakan suatu perbuatan hukum yang bertujuan memindahkan hak dari satu pihak ke pihak lain. Salah satu dari peralihan hak atas tanah adalah melalui Hibah. Hibah yaitu suatu persetujuan dalam mana suatu pihak berdasarkan atas kemurahan hati, perjanjian dalam hidupnya memberikan hak milik atas suatu barang kepada pihak kedua secara percuma dan yang tidak dapat ditarik kembali, sedangkan pihak kedua menerima baik penghibahan ini.

Salah satu contoh hak atas tanah yang dapat dialihkan melalui hibah adalah Hak Milik. Hak Milik yaitu hak turuntemurun, terkuat dan terpenuh yang dapat dipunyai orang atas tanah, dengan mengingat bahwa hak itu mempunyai fungsi sosial. Apabila sudah dilakukan peralihan hak atas tanah maka harus segera didaftarkan tanahnya di Kantor Pertanahan atau yang biasa disebut dengan pendaftaran tanah.

Secara khusus, pada saat penulis melakukan pra penelitian, permasalahan dalam Analisis Prosedur Pengadministrasian Peralihan Hak Atas Tanah Hibah pada Kementerian Agraria dan Tata Ruang / Badan Pertanahan Nasional Kabupaten Bungo Provinsi Jambi ditemukan beberapa fenomena diantaranya :

1. Masih tingginya jumlah masyarakat yang belum memahami tentang Peralihan Hak Atas Tanah Hibah.

2. Sarana dan Prasarana Kantor yang kurang di manfaatkan.

Masih tingginya jumlah masyarakat yang belum memahami tentang Peralihan Hak Atas Tanah Hibah.

\section{TINJAUAN PUSTAKA}

Menurut Spradley dalam Sugiyono (2014:89) mengatakan bahwa analisis adalah sebuah kegiatan untuk 
mencari suatu pola selain itu analisis merupakan cara berfikir yang berkaitan dengan pengujian secara sistematis terhadap suatu untuk menentukan bagian, hubungan antar bagian dan hubungannya dengan keseluruhan.

\section{Peralihan Hak Atas Tanah}

Peralihan hak atas tanah terjadi karena :

1. Perbuatan Hukum Pemindahan Hak.

Perbuatan hukum atas tanah yang bersangkutan sengaja dialihkan kepada pihak lain. Bentuk pemindahan haknya :

1) Jual Beli.

2) Tukar Menukar.

3) Hibah.

4) Pemberian Menurut Adat.

5) Pemasukan Dalam Perusahaan.

6) Hibah Wasiat.

2. Pewarisan Tanpa Wasiat

Dalam hukum perdata jika pemegang suatu hak atas tanah meninggalkan dunia, maka hak tersebut akan beralih kepada ahli waris karena secara otomatis hukum akan berpindah kepada ahli warisnya. Peralihan tersebut terjadi kepada para warisnya yaitu siapa-siapa yang termasuk ahli waris. Diberikan bagian masing-masing dan bagaimana cara membaginya diatur dalam hukum waris, almarhum pemegang hak yang bersangkutan bukan oleh hukum tanah yang bersangkutan.

\section{Hak Atas Tanah Dalam Hukum Tanah Nasional}

Menurut Boedi Harsono (2007:264) Dalam Hukum Tanah Nasional ada bermacam-macam hak penguasaan atas tanah sebagai berikut :

1. Hak Bangsa Indonesa (UUPA Pasal 1)

2. Hak Menguasai dari Negara (Pasal 2)

3. Hak Ulayat Masyarakat hukum adat sepanjang dalam kenyataannya masih ada (Pasal 3)

4. Hak-Hak Individu, yaitu :

Hak-hak Atas Tanah (Pasal 4) adalah sebagai berikut :

a) Primer, meliputi Hak Milik, Hak Guna Usaha, Hak

Guna Bangunan, yang diberikan oleh Negara (Pasal 16). b) Sekunder, meliputi Hak Guna Bangunan dan Hak Pakai, yang diberikan oleh pemilik tanah, Hak Gadai, Hak Usaha Bagi Hasil, Hak Menumpang, Hak Sewa dan Lain-lainnya (Pasal 37, 41, dan 53)

c) Wakaf (UUPA Pasal 49 dan Undang-Undang 41/2004).

d) Hak Jaminan atas tanah: Hak Tanggungan (UUPA Pasal 23, 33, 39, 51 dan Undang-Undang 4/1996);

\section{Undang-Undang Agraria}

Dalam Undang-Undang Pokok Agraria (UUPA) tidak di kenal hak atas tanah adalah "fungsi sosial", akan tetapi setiap hak atas tanah mempunyai fungsi sosial. Dengan kata "mempunyai fungsi sosiail" ini maka hak-hak atas tanah yang ada pada seseorang itu akan tetap dihormati. Sebagaimana di sebutkan dalam Pasal 6 UUPA bahwa semua hak atas tanah mempunyai fungsi sosial.

Dalam penjelasan Umum II angka (4) UUPA disebutkan bahwa semua hak atas tanah mempunyai fungsi sosial berarti bahwa hak atas tanah apapun yang ada pada seseorang, tidaklah dapat dibenarkan, bahwa tanahnya itu akan dipergunakan atau tidak dipergunakan semata-mata untuk kepentingan pribadinya, apalagi kalau hal itu menimbulkan kerugian bagi masyarakat. Penggunaan tanah harus sesuai dengan keadaannya dan sifat daripada haknya, hingga bermanfaat pula bagi masyarakat dan negara. Ketentuan tersebut tidak berarti bahwa kepentingan perorangan akan terdesak sama sekali oleh kepentingan umum (masyarakat). UUPA menghormati serta memperhatikan hak-hak dan kepentingankepentingan perorangan atas bidang tanahnya. Selanjutnya kepentingan masyarakat dan kepentingan perseorangan haruslah saling mengimbangi, hingga pada akhirnya akan tercapai tujuan pokok : kemakmuran, keadilan, dan kebahagiaan bagi rakyat seluruhnya.

Boedi Harsono mengemukakan bahwa salah satu tujuan UUPA sebenarnya bukan menambah pembatasan atau mengurangi kebebasan individu dalam menentukan peruntukan dan penggunaan tanah yang dipunyainya, karena hal itu sudah terkandung dalam sifat hakekat hak yang ada padanya. Tujuan UUPA justru akan memperkuat kedudukan individu dalam hubungan dengan masyarakatnya dan anggota masyarakat yang lain yakni dengan menyediakan perangkat peraturan hukum yang tertulis dan memberikan surat tanda bukti pemilikan tanah, melalui penyelenggaraan pendaftaran tanah. Dengan demikian apa yang tercantum dalam UUPA tersebut sebenarnya 
merupakan pokok-pokok pembatasan kebebasan individu yang sudah ada dalam menggunakan haknya atas bagian dari tanah bersama yang dipunyai.

Pendapat yang berbeda dikemukakan oleh Ronald Z. Titahelu yang mengemukakan bahwa fungsi sosial tidak saja dipergunakan untuk menerangkan kata tanah atas hak atas tanah, tetapi juga mempergunakan untuk menerangkan kata hukum. Fungsi sosial dapat diartikan sebagai suatu daya kerja kemsyarakatan tertentu yang timbul atau hancur pada waktu sesuatu di gerakan, diaktifkan, atau dikerjakan. Ada karakteristik tertentu yang menunjukana adanya daya kerja kemasyarakatan. Dengan demikian dibutuhkan karakteristik tertentu untuk menandai arti dari tanah memiliki fungsi sosial, maupun fungsi sosial dari hukum.

\section{Administrasi}

Menurut Ali Faried (2011:19) Administrasi adalah mengurus, mengatur, mengelola. Jika dibubuhi oleh awalan pe dan an pada setiap arti, maka semuanya mengandung maksud adanya keteraturan dan pengaturan sebab yang menjadi sasaran dari penguasaan, pengelolaan dan apa lagi pengaturan adalah terciptanya keteraturan dalam susunan dan pengaturan dinamikanya.

\section{Menurut Soewarno Handayaningrat 1996:2)}

Administrasi dapat dibedakan dalam dua pengertian:

1. Administrasi dalam arti sempit, yaitu berasal dari kata Administratie (bahasa Belanda), yang meliputi kegiatan catat mencatat, surat menyurat, pembukuan ringan, ketik mengetik, agenda, dan sebagainya yang bersifat ketata usahaan.

2. Sedangkan administrasi dalam arti luas, yaitu berasal dari kata Administration (bahasa Inggris), yang bearti administrasi sebagai kegiatan yang dilakukan oleh dua orang atau lebih (kelompok) yang mengadakan kerja sama untuk mencapai tujuan bersama.Pengertian diatas, menunjukkan bahwa administrasi merupakan proses yang bertanggung jawab terhadap penentuan tujuan dari organisasi sedangkan manajemen merupakan proses yang akan merealisasikan dari tujuan yang ditetapkan oleh organisasi sebelumnya.

Administrasi ditinjau dari sudut proses adalah kegiatan yang dilakukan untuk mencapai tujuan, dimulai dari proses pemikiran, proses pelaksanaan, sampai proses pencapaian tujuan itu sendiri. Sedangkan ditinjau dari sudut fungsinya ialah bahwa di dalam sagala kegiatan untuk mencapai tujuan itu terdapat berbagai fungsi-fungsi atau tugas-tugas itu dimulai dari perencanaan, mengorganisasi, menggerakkan sampai pada tugas mengawasi atau mengendalikan. Selanjutnya ditinjau dati sudut institusional atau kelembagaan yaitu administrasi sebagai suatu totalitas kelembagaan. Di dalam lembaga itu terdapat kegiatan untuk mencapai tujuan.

Sondang P. Siagian (1985:53) Administrasi sama usianya dengan peradaban manusia. Keberadaan ini dapat dibuktikan dengan menelaah unsur-unsur administasi. Secara singkat dapat dikatakan bahwa terdapat lima unsur dari administrasi yaitu:

1. Tujuan dan sasaran yang hendak dicapai. Pembenaran terkuat dari eksistensi administrasi adalah untuk mencapai tujuan dan berbagai sasaran. Yang menarik untuk diperhatikan ialah bahwa tujuan dan dasar yang ingin dicapai, dapat merupakan tujuan bersama dari orang-orang yang terlibat dari pencapaiannya.

2. Dua orang atau lebih yang baik secara formal atau informal terikat secara bersama terlibat dalam usaha pencapaian tujuan yang ditetapkan.

3. Adanya kegiatan yang harus diselenggarakan.

4. Keterlibatan bersama dalam pelaksanaan kegiatan organisasi.

5. Alat kerja yakni berbagai sarana dan prasarana yang diperlukan untuk menyelenggarakan berbagai kegiatan yang ada kaitan langsung dengan tercapainya tujuan. 


\section{Unsur-Unsur dan Sifat Perjanjian Hibah}

Agar dapat dikatakan tentang sesuatu "pemberian", perbuatan itu harus bertujuan memberikan suatu hadiah belaka jadi tidak boleh ada suatu keharusan atau perikatan meskipun hanya berupa natuurlijke verbintenis (janji dengan sendirinya) saja. Perkataan "pemberian" dalam pasal 1666 Kitab Undang-undang Hukum Perdata dipakai dalam arti kata yang sempit, karena hanya perbuatan- perbuatan yang memenuhi syarat-syarat yang disebutkan disitu dinamakan "pemberian", misalnya syarat dengan "Cuma-cuma" yaitu tanpa pembayaran. Di sini dapat dikatakan tentang suatu " formele schenking" ( hanya untuk memenuhi formalitas pemberian/hibah).

Hal-hal dalam perjanjian hibah yaitu :

1) Obyek

Menurut ketentuan yang terdapat dalam pasal 1667 KHUPerdata yang berbunyi :

"Hibah hanyalah dapat mengenai benda-benda yang sudah ada. Jika hibah itu meliputi benda-benda yang baru akan ada di kemudian hari, maka sekadar mengenai itu hibahnya batal"

Dari ketentuan yang terdapat dalam pasal diatas, maka dapat diketahui bahwa perjanjian hibah adalah benda yang sudah ada, baik berupa benda bergerak maupun benda tidak bergerak.

2) Larangan

Hal-hal yang tidak boleh dilakukan dalam penghibahan adalah sebagai berikut :

a) Kitab Undang-undang Hukum Perdata pasal 1668 menyebutkan $\mathrm{Si}$ penghibah tidak boleh memperjanjikan bahwa ia tetap berkuasa untuk menjual atau memberikan kepada orang lain suatu benda yang termasuk dalam hibah, hibah semacam itu, sekedar mengenai benda tersebut, diangggap sebagai batal.

b) Kitab Undang-undang Hukum Perdata pasal 1670 menyebutkan suatu hibah adalah batal, jika dibuat dengan syarat bahwa si penerima hibah akan melunasi utang-utang atau beban-beban lain, selain yang dinyatakan dengan tegas didalam akta hibah sendiri atau di dalam suatu daftar yang ditempelkan padanya.

c) Dalam Kitab Undang-undang Hukum Perdata pasal 1678 menyebutkan “ Dilarang adalah penghibahan antara suami istri selama perkawinan".

d) Berdasarkan KUHPerdata pasal 1684, Penghibahan-penghibahan yang diberikan kepada seorang perempuan bersuami, tidak dapat diterima selain menurut ketentuanketentuan dari Bab ke V buku ke I KUHPerdata.

3. Tata Cara Penghibahan

a) Berdasarkan Pasal 1682 KUHPerdata menyebutkan tiada suatu hibah, kecuali yang disebutkan dalam pasal 1687, dapat atas ancaman batal, dilakukannya selainnya dengan suatu akta notaris, yang aslinya disimpan oleh notaris itu.

b) Berdasarkan Pasal 1683 KUHPerdata menyebutkan tiada suatu hibah mengikat si penghibah, atau menerbitkan suatu akibat yang bagaimanapun, selain mulai hari penghibahan itu dengan kata-kata yang tegas telah diterima oleh si penerima hibah itu sendiri atau oleh seorang yang dengan sesuatu akta otentik oleh si penerima hibah itu telah dikuasakan untuk menerima penghibahan-penghibahan yang telah kepada si penerima hibah atau akan diberikan kepadanya kenudian hari.

c) Berdasarkan Pasal 1685 KUHPerdata menyebutkan penghibahan kepada orang-orang belum dewasa berada di bawah kekuasaan orang tua harus diterima oleh orang yang melakukan kekuasaan orang tua. Penghibahan kepada orang-orang belum dewasa yang berada dibawah perwalian atau orang-orang terampu, harus diterima oleh si wali atau si pengampu, yang untuk itu harus dikuasakan oleh Pengadilan Negeri.

d) Berdasarkan Pasal 1686 KUHPerdata menyebutkan hak milik atas benda-benda yang termaktub dalam penghibahan, sekalipun penghibahan itu telah diterima secara sah, tidaklah berpindah kepada si penerima hibah, selain dengan jalan penyerahan yang dilakukan menurut pasal-pasal 612, 1613, 616, dan selanjutnya.

e) Berdasarkan Pasal 1687 KUHPerdata menyebutkan pemberian-pemberian benda- 
benda bergerakan yang bertubuh atau surat-surat penagihan utang kepada si penunjuk dari tangan satu ke tangan yang lain, tidak memerlukan suatu akta, dan adalah sah dengan penyerahan belaka kepada si penerima hibah atau kepada seorang pihak ketiga yang menerima pemberian itu atas nama si penerima hibah.

4. Hal-hal yang membatalkan Akta Hibah.

Hal-hal yang membatalkan akta hibah telah dijelaskan dalam pasal 1688 BW. Suatu hibah tidak dapat ditarik kembali maupun dihapuskan karenanya, melainkan dalam halhal berikut :

a) Karena tidak dipenuhi syarat-syarat dengan mana pengibahan telah dilakukan.

b) Jika si penerima hibah telah bersalah melakukan atau membantu melakukan kejahatan yang mengambil jiwa si penghibah atau suatu kejahatan lain terhadap si penghibah.

c) Jika ia menolak memberikan tunjangan nafkah kepada si penghibah, setelah orang ini jatuh dalam kemiskinan. Namun demikian, tidak diatur dengan jelas batasan jumlah harta/benda/barang yang dapat dihibahkan sehingga juga perlu melihat bagian kedua $\mathrm{BW}$, khususnya pasal-pasal yang memuat ketentuan tentang batasan legitime portie, yakni pasal 913, 949, dan 920, serta peraturan perundang-undangan lainya seperti Undang-Undang No.1 Tahun 1974. Selain itu, adanya unsur perbuatan melawan hukum dalam hal penghibahan dapat pula membatalkan akta hibah. Ketidakcermatan Kantor Kementerian Agraria dan Tata Ruang/ Badan Pertanahan Nasional Kabupaten Bungo dalam menerbitkan sertifikat yang berasal dari hibah palsu seringkali terjadi karena tidak meneliti apakah hibah betul-betul dibuat oleh PPAT atau tidak. Akibatnya, berbagai sengketa tanah dengan sertifikat berasal dari hibah palsu yang bermunculan. Agar menjadi alat bukti yang sah, akta hibah harus dibuat dan ditandatangani oleh pejabat yang berwenang serta para pihak yang terkait di dalamnya. Selain itu, dalam pembuatan akta hibah, perlu diperhatikan objek yang akan dihibahkan, karena dalam PP Nomor 24 Tahun 1997 ditentukan bahwa untuk objek hibah tanah harus dibuat akta hibah oleh Pejabat Pembuat Akta Tanah (PPAT). Akan tetapi, apabila objek tersebut selain dari itu (objek hibah benda bergerak), maka ketentuan dalam BW tersebut tetap digunakan sebagai dasar pembuatan akta hibah, yakni dibuat dan ditandatangani Notaris.

\section{METODOLOGI}

Metode penelitian yang digunakan pada penelitian ini adalah Metode pendekatan kualitatif deskriptif. Penelitian ini mengambil lokasi di Kabupaten Bungo Provinsi Jambi. Jumlah sampel sebanyak 60 Orang. Dalam pelaksanaan penelitian ini digunakan beberapa pengumpulan data yaitu dengan wawancara, observasi, kuesioner

\section{HASIL DAN PEMBAHASAN}

Analisis Prosedur Administrasi Peralihan Hak Atas Tanah Hibah di Kantor Kementerian Agraria dan Tata Ruang/ Badan Pertanahan Nasional Kabupaten Bungo Provinsi Jambi.

Tanah merupakan sumber kehidupan bagi makhluk hidup baik manusia, hewan, atau tumbuh-tumbuhan. Manusia hidup dan tinggal di atas tanah dan memanfaatkan tanah untuk sumber kehidupan dengan menanam tumbuh-tumbuhan yang menghasilkan makanan. Mengingat begitu pentingnya tanah karena dapat menghasilkan sumber daya alam yang sangat bermanfaat bagi orang banyak maka perlu diatur oleh pemerintah. Undang- Undang Dasar 1945 Pasal 33 ayat 3 berbunyi : "Bumi dan air dan kekayaan alam yang terkandung di dalamnya dikuasai oleh negara dan dipergunakan untuk sebesarbesar kemakmuran rakyat". 
Seperti yang dinyatakan oleh Bapak Anggasana Siboro bahwa Hibah merupakan suatu perjanjian dimana pihak yang satu menyanggupi dengan cuma-cuma secara mutlak memberikan suatu benda pada pihak yang lain. Sebagai suatu perjanjian, pemberian itu seketika mengikat dan tidak dapat dicabut kembali begitu saja menurut kehendak satu pihak. Tata cara pengadministrasian peralihan hak atas tanah hibah, untuk tanah yang sudah bersertifikat pemberi hibah dan penerima hibah menghadap pejabat pembuat akta tanah (PPAT) untuk menanda tangani akta hibah. Adapun Syarat-syarat Hibah sebagai berikut :

1. Identitas diri Pemberi Hibah.

2. Kartu Keluarga Pemberi Hibah dan Penerima Hibah.

3. SPPT PBB Tahun Terakhir atas nama pemberi hibah.

4. Identitas diri penerima hibah.

5. Membuat Surat pernyataan bahwa harta yang di hibahkan tidak melebihi sepertiga dari harta warisan.

6. Membayar pajak peralihan apabila melebihi ketentuan NJOP sesuai ketentuan.

Proses pembuatan akta hibah, pemberi hibah harus melengkapi data tanah dan data pemberi maupun penerima hibah. Untuk data tanah, yang mutlak harus ada adalah asli sertipikat tanah dan asli SPPT dan STTS PBB 5 (lima) tahun terakhir. Dokumen lain yang dapat diberikan, namun tidak mutlak adalah asli IMB, rekening pembayaran air, telpon, listrik dan lain sebagainya yang berhubungan dengan tanah serta bangunan yang menjadi objek hibah. Untuk data pemberi dan penerima hibah, KTP suami/istri, kartu keluarga, akta nikah, akta kelahiran jika hibah dalam garis lurus ke atas/ke bawah satu derajat, kesemuanya dalam bentuk foto copy. Beberapa hari sebelum penandatanganan akta hibah, serahkan semua syarat tersebut kepada Camat, maka Camat akan melakukan pengecekan/checking sertipikat di kantor BPN setempat. Pemberi hibah harus mengurus Surat Keterangan Bebas Pajak Penghasilan (SKB PPh) dengan mengajukan permohonan di kantor Pelayanan Pajak setempat, kemudian penerima hibah harus melunasi BPHTB hibah. Setelah semua terpenuhi, penandatanganan akta hibah dapat dilaksanakan, untuk kemudian Camat mendaftarkan proses balik nama sertipikat tersebut."

Dari penjelasan oleh Kepala Kantor Pertanahan Kabupaten Bungo dapat disimpulkan bahwa Hibah merupakan suatu perjanjian dimana pihak yang satu menyanggupi dengan cuma-cuma secara mutlak memberikan suatu benda pada pihak yang lain. Sebagai suatu perjanjian, pemberian itu seketika mengikat dan tidak dapat dicabut kembali begitu saja menurut kehendak satu pihak. Tata cara pengadministrasian peralihan hak atas tanah hibah, untuk tanah yang sudah bersertifikat pemberi hibah dan penerima hibah menghadap pejabat pembuat akta tanah (PPAT) untuk menanda tangani akta hibah. Proses pembuatan akta hibah, pemberi hibah harus melengkapi data tanah dan data pemberi maupun penerima hibah. Untuk data tanah, yang mutlak harus ada adalah asli sertipikat tanah dan asli SPPT dan STTS PBB 5 (lima) tahun terakhir. Dokumen lain yang dapat diberikan, namun tidak mutlak adalah asli IMB, rekening pembayaran air, telpon, listrik dan lain sebagainya yang berhubungan dengan tanah serta bangunan yang menjadi objek hibah. Untuk data pemberi dan penerima hibah, KTP suami/istri, kartu keluarga, akta nikah, akta kelahiran jika hibah dalam garis lurus ke atas/ke bawah satu derajat, kesemuanya dalam bentuk foto copy. Beberapa hari sebelum penandatanganan akta hibah, serahkan semua syarat tersebut kepada Camat, maka Camat akan melakukan pengecekan/checking sertipikat di kantor BPN setempat. Pemberi hibah harus mengurus Surat Keterangan Bebas Pajak Penghasilan (SKB PPh) dengan mengajukan permohonan di kantor Pelayanan Pajak setempat, kemudian penerima hibah harus melunasi BPHTB hibah. Setelah semua terpenuhi, penandatanganan akta hibah dapat dilaksanakan, untuk kemudian Camat mendaftarkan proses balik nama sertifikat tersebut.

Hibah adalah pemberian oleh seseorang kepada orang lainnya, secara Cuma-Cuma dan tidak dapat ditarik kembali, atas barang bergerak maupun barang tidak bergerak pada saat pemberi hibah tersebut masih hidup. Hibah harus memenuhi apa yang diatur dalam Pasal 1666 KUHPerdata, bahwa hibah merupakan pemberian oleh seseorang kepada orang lainnya secara cuma-cuma dan tidak dapat ditarik kembali, atas barangbarang bergerak maupun barang tidak bergerak pada saat pemberi hibah masih hidup, karena si pemberi hibah bertindak secara aktif menyerahkan kepemilikan barangnya kepada si penerima hibah. Karena sifatnya cuma-cuma, maka si pemberi hibah bebas dari $\mathrm{PPh}$, asalkan hibah dilakukan dari orang tua ke anak dan sebaliknya, namun jika antar saudara kandung ataupun ke orang lain, tetap dikenai PPh layaknya jual beli. “

Dapat disimpulkan apa yang telah disampaikan Kepala Sub Seksi Penetapan Hak Tanah Kantor Pertanahan Kabupaten Bungo Ibu Risyani bahwa kewenangan pembuatan 
akta hibah. Dalam Pasal 1682 Kitab Undang-Undang Hukum Perdata (untuk selanjutnya disebut dengan "KUHPerdata"), hibah barang bergerak harus dengan akta Notaris dan sedangkan hibah untuk Tanah dilakukan di hadapan Pejabat Pembuat Akta Tanah ("PPAT") sesuai Pasal 37 ayat (1) Peraturan Pemerintah No. 24 tahun 1997 tentang Pendaftaran Tanah, dengan menggunakan akta PPAT. Camat merupakan pejabat pemerintahan pemimpin wilayah yang terdiri dari beberapa kelurahan, yang disebut dengan kecamatan. Di wilayah-wilayah tertentu yang masih kurang PPAT, Camat karena jabatannya memiliki kewenangan sebagai PPAT Sementara. Untuk melayani masyarakat dalam pembuatan akta PPAT di daerah yang belum cukup terdapat PPAT atau untuk melayani golongan masyarakat tertentu dalam pembuatan akta PPAT tertentu, Menteri (untuk kemudian dilimpahkan kepada Kepala BPN Propinsi) dapat menunjuk Camat atau Kepala Desa untuk melayani pembuatan akta di daerah yang belum cukup terdapat PPAT, sebagai PPAT Sementara”.

Untuk Menganalisis dan Menjelaskan Hambatan dihadapi Kementerian Agraria dan Tata Ruang / Badan Pertanahan Nasional Kabupaten Bungo Provinsi Jambi Dalam Analisis Prosedur Administrasi Peralihan Hak Atas Tanah Hibah.

Adapun hambatan dalam Analisis Tinjauan Tata Cara Administrasi Peralihan Hak Atas Tanah Hibah sebagai berikut:

1. Masih tingginya jumlah masyarakat yang belum memahami tentang Peralihan Hak Atas Tanah Hibah.

Masih banyaknya terdapat persyaratan yang diajukan oleh masyarakat kurang lengkap, sehingga mengakibatkan pegawai menolak dokumen yang diajukan masyarakat. Hal ini senada dengan argumen yang diungkapkan oleh Bapak Anggasana Siboro selaku Kepala Kantor Pertanahan Nasional Kabupaten Bungo, beliau mengatakan: Minimnya pengetahuan masyarakat akan arti pentingnya bukti kepemilikan peralihan hak atas tanah hibah. Untuk proses kepengurusan persyaratan, maka mereka harus memiliki surat-surat kelengkapan untuk tanah yang mereka miliki, akan tetapi pada kenyataannya masyarakat banyak yang tidak memahami hal itu. Peralihan hak atas tanah karena hibah tidak serta merta terjadi pada saat tanah diserahkan oleh pemberi hibah kepada penerima hibah. Berdasarkan Pasal 37 PP No. 24 Tahun 1997 dinyatakan bahwa peralihan hak atas tanah harus dibuktikan dengan akta yang dibuat oleh PPAT yang berwenang menurut peraturan perundang - undangan yang berlaku.

2. Sarana dan Prasarana Kantor yang kurang di manfaatkan.

Masalah lain yang timbul pada umumnya yang dapat menjadi penghambat dalam peralihan hak atas tanah hibah adalah minimnya pemanfaatan sarana dan prasarana kantor. Pengarsipan dokumen-dokumen di Kantor Pertanahan umumnya masih dilakukan secara manual. Dalam pasal 35 ayat (5) PP No. 24 Tahun 1997 berbunyi "secara bertahap data pendaftaran tanah dan peralihan hak atas tanah hibah disimpan dan disajikan dengan menggunakan peralatan elektronik ". Hal ini dilaksanakan untuk menghemat tempat dan mempercepat akses pada data yang diperlukan. Akan tetapi Kantor Pertanahan belum melaksanakan keputusan tersebut karena masih terkendala pada sarana/prasarana yang terbatas.

Hal senada juga disampaikan oleh Risyani, bawah Selain itu efek yang timbul dari terbatasnya sarana dan prasarana adalah Pengarsipan dokumendokumen di Kantor Pertanahan umumnya masih dilakukan secara manual sehingga memperlambat akses pada data yang diperlukan.

Berdasarkan hasil wawancara dengan Anggasana Siboro, bahwa kurangnya keterampilan yang dimiliki oleh pegawai kantor pertanahan nasional kabupaten bungo dalam memanfaatkan sarana dan prasarana. Dimana dapat dilihat bahwa masih terdapat kurangnya keterampilan pegawai yang ada di kantor pertanahan kabupaten bungo dalam menggunakan kelengkapan elektronik seperti komputer yang digunakan dalam menulis data yang akan digunakan. Hal ini berdampak pada keterlambatan dalam penyelesaian tugas. Disamping itu penyelesaian tugas yang membutuhkan tingkat kebutuhan yang mendadak tidak dapat diselesaikan dengan segera karena disebabkan pegawai yang akan menyelesaikan tugas yang berhubungan dengan komputer tidak berada di tempat.

Berdasarkan hasil wawancara dengan Vito Haga Mursa: Jumlah porsonil yang ada di kantor bagian administrasi pelayanan masih sangat kurang dan kurangnya keterampilan pegawai yang ada di kantor pertanahan kabupaten bungo dalam 
menggunakan kelengkapan elektronik seperti komputer yang digunakan dalam menulis data yang akan digunakan. Hal senada juga disampaikan oleh Batara mengatakan bahwa : Penyelesaian tugas yang membutuhkan tingkat kebutuhan yang mendadak tidak dapat diselesaikan dengan segera karena disebabkan pegawai yang akan menyelesaikan tugas yang berhubungan dengan komputer tidak berada di tempat

3. Kurangnya Kedisiplinan Pegawai

Berdasarkan hasil wawancara dengan Anggasa Siboro, bahwa Tingkat keberhasilan kinerja kantor pertanahan nasional Kabupaten Bungo dalam peralihan hak atas tanah hibah masih sangat minim. Salah satu pemicunya adalah Dimana melihat kondisi pegawai masih ditemukan pegawai yang mengindahkan disiplin yang telah ditetapkan. sehingga akan berdampak kepada pelayanan kebutuhan masyarakat yang akan menimbulkan opini bahwa tingkat pemahaman dan pelayanan tidak berjalan dengan baik. Sehingga untuk mendapatkan pelaksanaan tugas yang cepat, belum dapat berjalan dengan maksimal.

\section{SIMPULAN}

Berdasarkan hasil penelitian dan analisa yang telah penulis lakukan maka pada bab ini dapatlah disimpulkan bahwa Analisis Prosedur Administrasi Peralihan Hak Atas Tanah Hibah di Kabupaten Bungo Provinsi dapat ditarik kesimpulan sebagai berikut :

1. Analisis Prosedur Administrasi Peralihan Hak Atas Tanah Hibah di Kantor Kementerian Agrarian dan Tata Ruang/ Badan Pertanahan Nasional Kabupaten Bungo. Tata cara pengadministrasian peralihan hak atas tanah hibah, untuk tanah yang sudah bersertifikat pemberi hibah dan penerima hibah menghadap pejabat pembuat akta tanah (PPAT) untuk menanda tangani akta hibah. Adapun Syarat-syarat Hibah sebagai berikut :

a) Identitas diri Pemberi Hibah.

b) Kartu Keluarga Pemberi Hibah dan Penerima Hibah.

c) SPPT PBB Tahun Terakhir atas nama pemberi hibah.

d) Identitas diri penerima hibah.

e) Membuat Surat pernyataan bahwa harta yang di hibahkan tidak melebihi sepertiga dari harta warisan. f) Membayar pajak peralihan apabila melebihi ketentuan NJOP sesuai ketentuan.

Proses pembuatan akta hibah, pemberi hibah harus melengkapi data tanah dan data pemberi maupun penerima hibah. Untuk data tanah, yang mutlak harus ada adalah asli sertipikat tanah dan asli SPPT dan STTS PBB 5 (lima) tahun terakhir. Dokumen lain yang dapat diberikan, namun tidak mutlak adalah asli IMB, rekening pembayaran air, telpon, listrik dan lain sebagainya yang berhubungan dengan tanah serta bangunan yang menjadi objek hibah. Untuk data pemberi dan penerima hibah, KTP suami/istri, kartu keluarga, akta nikah, akta kelahiran jika hibah dalam garis lurus ke atas/ke bawah satu derajat, kesemuanya dalam bentuk foto copy. Beberapa hari sebelum penandatanganan akta hibah, serahkan semua syarat tersebut kepada Camat, maka Camat akan melakukan pengecekan/checking sertipikat di kantor BPN setempat. Pemberi hibah harus mengurus Surat Keterangan Bebas Pajak Penghasilan (SKB $\mathrm{PPh}$ ) dengan mengajukan permohonan di kantor Pelayanan Pajak setempat, kemudian penerima hibah harus melunasi BPHTB hibah. Setelah semua terpenuhi, penandatanganan akta hibah dapat dilaksanakan, untuk kemudian Camat mendaftarkan proses balik nama sertipikat tersebut."

2. Hambatan Kantor Kementerian Agraria dan Tata Ruang/ Badan Pertanahan Nasional Kabupaten Bungo Dalam Peralihan Hak Atas Tanah Hibah adalah masih tingginya jumlah masyarakat yang belum memahami tentang Peralihan Hak Atas Tanah Hibah, Sarana dan Prasarana Kantor yang kurang di manfaatkan, Kurangnya Kedisiplinan Pegawai.

3. Upaya Kantor Kementerian Agraria dan Tata Ruang/ Badan Pertanahan Nasional Kabupaten Bungo untuk mengatasi hambatan yang dihadapi dalam peralihan hak atas tanah hibah adalah dengan memberikan pembinaan dan pengarahan kepada jajaran instansi pemerintah di tingkat Kecamatan dan Kelurahan/Dusun bekerjasama dengan Dinas terkait dalam rangka pengendalian dan pemberdayaan masyarakat terhadap masalah peralihan hak atas tanah hibah, melalui program pelayanan informasi pertanahan, meningkatkan sarana dan prasaranan kerja /operasional terutama untuk keperluan pelayanan dan pengarsipan, serta meningkatkan disiplin kerja pegawai. 


\section{DAFTAR PUSTAKA}

Boedi Harsono, Hukum Agraria Indonesia, Sejarah Pembentukan UUPA, Isi dan Pelaksanaannya, Jilid 1 Hukum Tanah Nasional, Jakarta: Djambatan, 2007.

Efendi Perangin, Pratek Jual Beli Tanah, Jakarta: CV. Rajawali, 1987

Husaini Usman dan Purnomo Setiadi A. Metodologi Penelitian Sosial, Jakarta: Bumi Aksara, 2003.

Maria S.W. Sumardjono, Tanah Dalam Prespektif Hak Ekonomi, Sosial dan Budaya, Jakarta: Kompas, 2008.

Sugiyono, Metodologi Penelitian Administrasi, Bandung: Alfabeta, 2000 .

Winarno Surachmad, Pengantar Penelitian Ilmiah Dasar, Metode dan Teknik, Bandung: Tarsito, 1995. 